International Journal of Linguistics, Literature and Translation

ISSN: 2617-0299 (Online); ISSN: 2708-0099 (Print)

DOI: 10.32996/ijltt

Journal Homepage: www.al-kindipublisher.com/index.php/ijltt

\title{
English Reading Texts Model Using the Ecoliteracy Lexicons Approach
}

\author{
Suparman ${ }^{1}$ 8(D) $\triangle$, Ida Bagus Putra Yadnya ${ }^{2}$ (D), I Wayan Simpen ${ }^{3}$ \& (D) and Made Sri Satyawati ${ }^{4}$ (D) \\ ${ }^{1}$ Lecturer of English Language Teaching, STKIP Paracendekia NW Sumbawa, Sumbawa, Indonesia \\ ${ }^{234}$ Lecturer of Linguistic Program, Udayana University, Denpasar, Indonesia
}

$\triangle$ Corresponding Author: Suparman, E-mail: mansupar52@gmail.com

ARTICLE INFORMATION

Received: March 08, 2021

Accepted: April 22, 2021

Volume: 4

Issue: 4

DOI: $10.32996 /$ ijllt.2021.4.4.15

\section{KEYWORDS}

English, reading, text, model, ecoliteracy, lexicons

\section{ABSTRACT}

This article discusses the English reading texts model using the Ecoliteracy Lexicons. The study aims to design and develop an example of English reading text by using the ecological or environment lexicons. This study applied the Educational Research and Development (R \& D) method. It was conducted in Sumbawa District, West Nusa Tenggara Province, Indonesia. The instruments of this study were the validation sheet, a questionnaire sheet and a documentation instrument. The result of the study revealed that there are four types of English reading texts based on the ecoliteracy lexicons. The first is the English reading text-based-beaches marine lexicons, which have developed and designed the text using ecological lexicon Jempol Beach and Goa Beach lexicon. The second is the English reading text-based-historical architecture environment lexicons constructed the text by applying two ecological lexicons of Dalam Loka palace and Bala Puti Palace. The third is the English reading text-basedmarine archipelagos environment lexicons, which used the Moyo Island and Ngali Island's ecological lexicons in developing and designing the English reading text. The last one is the English reading text-based- traditional farmland environment lexicons, which was developed and designed using the ecological lexicons of Orong and Uma.

\section{Introduction}

Some students in Asia, who have different cultural backgrounds and lifestyles from Western countries, no longer focus on mastering English. Therefore, they should create a new climate in learning English, for example, forming an English community in Asian countries or what was called Englishes. People learn English to communicate with native speakers to exchange ideas and views on culture, social, cultural, art, lifestyle, food, and so on.

The reality of learning English taking place in Indonesia has experienced some gaps. These gaps occur due to the contents in English textbooks which are America and British English-oriented. The unclear content of the teaching materials in English books results in a lack of student association power in understanding the reading texts available in the imported textbooks. Student association power was needed to improve student's cognitive processes by bringing the environment or ecology of students into the classroom, be it the physical, social, and cultural environment.

The ecology of students would be introduced in the classroom through the development of English teaching materials on reading skills. Reading English skills was challenging for students in Indonesia, especially in understanding the reading texts in English books. This constraint was caused by the students' lack of knowledge about reading material and the inability of students to connect ideas between sentences. According to Rahmawati (2011) which states that:

"The problem faced in understanding the reading text lies in the lack of knowledge about reading material and not knowing how to connect ideas between sentences to one another (Rahmawati, 2011)."

\section{K C AL-KINDI CENTER $\mathbf{R}$ D FOR RESEARCH AND DEVELOPMENT} Your gateway to world-class research

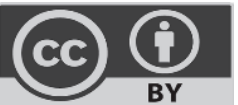

Published by Al-Kindi Center for Research and Development, London, United Kingdom. Copyright (c) the author(s). This open access article is distributed under a Creative Commons Attribution (CC-BY) 4.0 license 
Rahmawati stated that some students lack knowledge of reading material, resulting in the inability of students to connect ideas between one sentence and another. The students' lack of knowledge of reading material was caused by the students' low mastery of vocabulary. Megawati also explained the same thing (2016: 153-154) says that the difficulty in understanding the contents of reading in English was due to the low vocabulary mastery so that the messages contained in what they read were challenging to interpret. Furthermore, Yusril, et al. (2018) explains that the difficulty in understanding reading was caused by several factors such as the lack of students' vocabulary.

Reading skills are complex language skills. Students were required to read and identify symbols in a reading text and associate with their understanding and apply reading ideas in everyday life. Reading skills need to be taught to students because the mother tongue (Indonesian) and foreign language (English) have differences, for example, in structure (grammar), word recognition (vocabulary), and so on. Therefore, students need proper and correct guidance and guidance.

The reading and writing skills of students in Indonesia had not been maximally developed based on the results of a UNESCO study through the Program for International Student Assessment (PISA) in 2003, which showed that the reading skills of children in Indonesia aged 15 years and over ranked 39th out of 41 countries studied. From the number studied, it appears that 37.6\% can only read without being able to grasp the meaning, and 24.8\% can only draw one knowledge conclusion (Suryaman, 2012: 37).

Based on the empirical facts above, it was related to the low ability of students in Indonesia in mastering and understanding English reading texts in student textbooks. The problem of reading becomes the basis for conducting this research. This study used a new approach to design teaching materials in reading skills. The new approach referred to in this study was the ecoliteracy lexicons approach.

Using this ecoliteracy lexicons approach, the English reading text is based on the ecoliteracy lexicon in Sumbawa, West Nusa Tenggara Province of Indonesia. These texts constructed based on ecology contain reading teaching materials taken from the students' environment. Futhermore, this study tried to introduce strategies to increase students' understanding of the environment in the classroom. These strategies can be promoted in the context of eco-literacy education through understanding the ecoliteracy, for the sake of growing love for the environment.

\section{Literature Review}

\subsection{Ecoliteracy}

Ecoliteration seeks to introduce and renew people's understanding of the importance of global ecological awareness to create a balance between people's needs and the earth's ability to sustain them. Capra (1995) explains that ecoliteracy is:

"The great challenge of our time is to build and nurture sustainable communities-communities that are designed in such a way that their ways of life, businesses, economies, physical structures, and technologies do not interfere with nature's inherent ability to sustain life. The first step in this endeavour is to understand the principles of organization that ecosystems have developed to sustain the web of life. This understanding is what we call ecological literacy (Capra, 1995)."

At first, ecoliteracy was better known as ecological awareness. Hyun (2000) explains that humans have an awareness of ecology but that human consciousness must be raised through knowledge and understanding of the universe. The goal is that this awareness appears to be a behavior that appears natural in protecting the earth where humanity lives. However, ecoliteracy does not mean that people just raise awareness to care for the environment and understand the operation of ecological principles in a sustainable coexistence on planet earth. The researchers believe that the principles of ecology guide the direction for the creation of a learning community based on sustainable development.

There are three performance principles in ecoliteracy, namely: (1) people must be ecologically literate as the principle of the first stage of the development of sustainable communities; (2) the second stage is what is called eco-design, or ecological design. Ecodesign can be applied in almost all fields. People know it in phrases that are becoming common lately, such as eco economy, ecocity, eco-farming, eco-technology, eco-psychology; and (3) the third stage of this process is forming sustainable communities that make them aware of the principles of ecology.

\subsection{Lexicon}

The lexicon comes from Ancient Greek. It means "word", "speech", or "way of speaking". The term lexicon is commonly used to accommodate the concept of a "collection of lexemes" from a language, either in whole or in part (Chaer, 2007: 2-6). The lexicon is known as "lexicography" which is a part of linguistic studies. Merrupak lexicography is essentially an object of study that is included in the field of macrolinguistic studies. It is said so because the things that are studied in lexicography are not only 
examining language as an independent phenomenon but have been linked with other disciplines. According to Setiawan (2015: 2), lexicography is "

"The opinion which states that lexicography is only concerned with the compilation of dictionaries is neither completely true nor completely wrong. This opinion is said to be not entirely correct because lexicographic studies are not solely related to dictionary compilation. Lexicography also deals with the theory and research of dictionaries. This opinion is also not entirely wrong because one of the areas of lexicography is compiling a dictionary. In other words, lexicography is not limited to the preparation of dictionaries. Lexicography also discusses dictionaries, namely the development and description of theories and methods (Setiawan, 2015: 2)."

The opinion above explains that lexicography is related to the preparation of dictionaries, the theory and method of development and the description of the dictionary itself. This is also confirmed by the opinion expressed by Bergenholtz and Tarp (2002: 31), which states that there are two aspects studied in lexicography, namely making dictionaries and dictionary research. Practical lexicography work includes writing and editing dictionaries, whereas theoretical lexicography focuses on studying language and vocabulary in cultural contexts and developing the best methods for compiling dictionaries. The concern of theoretical lexicography aims to develop a theory about the semantic and structural relationships of the words used in lexicons. Theoretical lexicography is often referred to as metallexicography.

So that the lexicon in this research is to apply the concept of theoretical lexicography, which aims to study language and collect vocabulary in the context of culture, customs, environment, social, arts, language, and the belief system of the Sumbawa Kabuapaten community. This is related to the lexicon concept described by Kridalaksana (2008) which states that the lexicon is a list of words about the natural environment around the learner's life which is accompanied by an explanation and also refers to the rich vocabulary of a learner, in this case, the research respondent.

\subsection{Reading}

In learning English, four skills must be mastered: listening, speaking, reading, and writing. In essence, reading was an activity that aims to get ideas, theories, and knowledge from reading books we learn, because reading is the center of science. According to Somadayo (2011), reading is one of the most important languages. Furthermore, Rubin (2011) argues that reading comprehension is a complex intellectual process that includes two main abilities: mastery of the meaning of words and thinking about verbal concepts. Besides that, Tarigan (2008) and Yunus (2012) say that:

"Another meaning of reading comprehension (reading for understanding) is a type of reading to understand literary standards or norms, research criticism, written drama, and fictional patterns to gain an understanding of the text. The reader uses certain strategies. Reading comprehension is a process in understanding the content of reading, for that we need a solution as a way out that at least can reduce the difficulty of students in reading various kinds of text books in English (Tarigan 2008, Yunus 2012)."

The above opinion points out reading is a process to understand and obtain information from what we get, so that various kinds of textbooks are used as media or tools to improve reading skills. Nurgiyantoro (2010:368) argues that reading is mental activity to understand what other parties say through writing. Nurgiyantoro, (2010: 283) states that reading activities are an effort to understand the information conveyed through written symbols. Reading activities are very important in everyday life, especially in language learning in schools.

Based on the overall opinion above, it can be concluded that reading is a language skill that has activities to speak, perceive, understand, and give meaning to visual symbols. Of course, reading activities must be accompanied by reading materials based on students' needs of the environment they live in. Likewise, all aspects of semiotics, signs and local lexicons should be considered when designing reading material in English.

\subsection{Lexical Semantic Relation}

In analyzing the ecology lexicon in the English reading texts, this study will be presented using the theory of "lexical semantic relations". The lexical-semantic relation was concerned with lexical meaning. Verhaar (2016: 388-380) states that lexical-semantic relations include a rather large number of aspects, including 1) meaning and references, 2) denotation and connotation, 3) extensional and intentional analysis, 4) comprehensive analysis, 5) meaning and the wearer, and 6) synonymy, Cantonese, homogeneous, and hipster.

Lexical semantic relations are defined as studying the semantics of words (lexicons). The semantics of words refer to lexical meanings. The lexical meaning in English is the study of the elements in language which are part of an object and event. In other words, the lexical meaning of emergence is caused by a relationship between language elements apart from usage (the context). 
Lexical semantic relations focus on the system of meaning contained in a word. Even the meaning system is closely related to the lexical structure, which creates various semantic relations in a word.

\section{Methodology}

\subsection{Research Design}

This study was part of "educational research and development" (R \& D). This is following the opinion of Borgn and Gall (1983: 772), who said that R \& D is defined as "a process used to develop and validate educational products that are ready for operational use in the school," which is a research model for developing and printing various kinds of products that are ready for use in schools. Borg and Gall (2003: 570-573) explains in more detail the procedures for developing and compiling R \& D, namely in the development steps of R\&D that include materials, procedures and processes. Development of R \& $D$ in Indonesia in education refers to the Development Model of Curriculum and Teaching Models in Basic Education, Secondary Education and Higher Education (Sukmadinata, 2005: 183).

The research design used in this research uses a research and development design in the form of the Borg and Gall (1983: 775776) development model because this teaching material development model offers the most appropriate stages for this research. In producing a model of reading texts for teaching English based on the eco-literacy lexicons of students senior high school in Sumbawa District, West Nusa Tenggara Province, Indonesia.

\subsection{Research Steps}

The steps developed by Dick and Carey (2005) were (1) identifying learning objectives, (2) analyzing current learning methods, (3) identifying initial behavior and student characteristics, (4) formulating specific instructional goals, (5) writing achievement indicators, (6) developing reference test items, (7) developing strategies and learning materials, and implementing them, (8) conducting model evaluations and (9) conducting instructional revisions.

While the R \& D model has been developed by Borg and Gall (1983: 775-776), there are ten stages in development, namely: (1) research and data collection (research and data collection), (2) planning, (3) ) development of a product draft (develop a preliminary form of product), (4) preliminary field testing, (5) revising the results of the main product revision, (6) field testing (main field testing), (7) Completion of product field test results (operational product revision), (8) operational field testing, (9) final product revision, and (10) dissemination and implementation.

Based on the research steps above, the writer just presented the English reading texts model without discussing the students scores gained, but the writer was going to discuss the text types and the ecoliteracy lexicons as the base for constructing the texts this research.

\subsection{Research Location}

This research was conducted in Sumbawa District, West Nusa Tenggara Province, Indonesia. The subjects of this study were students at Sumbawa Regency State Senior High School. They were in class X State Senior High School Negeri 1 Lape, grade X students of State Senior High School 1 Maronge, and class X State Senior High School 1 Plampang.

\subsection{Types and Sources of Data}

This study uses two data sources, namely primary data and secondary data. Primary data was the primary data used in conducting this research. Meanwhile, secondary data is supporting data for completing this research. The primary data in this study include (1) the text in the form of reading text in the X grade English book and (2) the form of verbal signs (lexicon) and visual signs (pictures). Verbal signs are the lexicon forms of local nouns, verbs and adjectives (flora, fauna and inanimate objects) in the district of Sumbawa, while visual signs (pictures) are related to mountainous, marine, rural, and urban environments in the district. Sumbawa. The secondary data, namely supporting data, was related to information about the current lesson plans, syllabus, and curriculum in 2013.

\subsection{Research Instruments}

The research instrument is a tool used by researchers to collect data in this study. According to Darmadi (2011: 85), an instrument's definition is a tool for measuring information or taking measurements. Sukarnyana et al. (2003: 71) state that research instruments are tools used to obtain or collect data. This study used three instruments, namely: validation sheet, a questionnaire sheet and documentation

\section{Results and Discussion}

The English reading text model developed in this study includes reading material for high school English students in grade $X$. It aims to show that the descriptive texts can exceed the minimum completeness criteria (KKM) that have been set from the three 
schools, namely the value of 7.00 . Furthermore, reading teaching materials in this study use three criteria guided by reading skills in the 2013 curriculum English book. The first criterion is learning English based on environmental texts, which is learning based on the structure and language of the text, learning based on this is information in the form of lexicon in English learning. The second criterion is that the learning resources used in learning to read descriptive texts in this research design book are closely related to student life so that it is easy for students to understand the descriptive texts that are made. The third criteria for teaching materials in the descriptive text are very attractive to students and impact increasing students' interest on reading and understanding the contents of the descriptive text in this book. Based on the above criteria, the teaching materials for reading in English books that were designed in the study consisted of several ecoliteracy lexicon topics. The selection of ecoliteracy lexicon topics was adjusted to environmental topics that are familiar with the daily lives of students, the material in each topic was easy to understand and effective when used in learning English in the classroom. The findings in this study relate to (1) text-based marine beaches, namely in the form of topics on the lexicon of Jempol Beach, Goa Beach, and Matti Mindai Beach. Furthermore, (2) the text based-historical architecture environment consists of two lexicons, namely the lexicon Dalam Loka Palace and Bala Puti Palace. Then, (3) text-based marine archipelagos environment consists of 2 lexicons, including the lexicon of Moyo island and Ngali island. Then, (4) the text-based traditional farmland environment consists of two lexicons, namely the lexicon of Orong, and Uma lexicons. Based on the findings of the English reading text model topics above, the following are the discussions of some reading texts based on the ecoliteracy lexicons taken from the student environment.

\subsection{English Reading Text Based-Beaches Marine Lexicons.}

Three lexicons were found in the English reading texts based on marine beaches lexicons. Those texts developed based on the coastal environment lexicons, namely the Jempol Beach, Goa Beach, and Matti Mindai Beach. The discussion of English reading texts based on the coastal environment will be discussed in the following:

\section{Jempol Beach}

Jempol beach is located in Labuhan Badas Village. It belongs to the Labuhan Badas district. Jempol beach stand for the 'Jembatan Polak' derived from Samawa Language means the broken ridge into two parts. The word 'Polak' means broken, cut off or opposite to the word 'Besai' in Sumbawanese means intact. Indeed, this bridge is cut off in two by the oldest factor and it is cut by the pounding waves when the seawater tide rises.

This bridge does not use as a port again since the Labuhan Badas Port build in the west part. Jempol beach often visits by teenagers and the oldest people. They come with their friends, mother, father, son, and daughter to drink Sumbawa traditional coffee or eat some traditional food of Sumbawa. In the past years, this bride is used by merchant ships to anchor from national and international ships. It builds after erupting the mount Tambora. It was built during the conduction of the Sultan of Muhammad Jalaludin II. In this bridge are any many vendors. They provide some kinds of Sumbawa culinary foods such as sepat, singang, jangan bage, surabi. In addition, the visitors cannot only drink a cup of coffee or eat some traditional culinary, but they can also see "selam matano" (sunset), keeps seeing the beautiful charm of the sea view around the bridge. Accompanied by seeing the activities of fishermen catch the fish, the fishermen use traditional boat called 'jukung' (big size boat) and 'sampan' (small size boat) in front of Jempol bridge. In this bridge area live many tribes such as Malayu, Mandar, Bajo, Sasak, Arab, and native Sumbawa knows as 'Tau Samawa'. (Sources: taken from private document).

Based on the English reading text, some of the ecoliteracy lexicons were found, which are the characteristics of these texts. Those ecolitercy lexicons were Jembatan, Polak, Besai, Sepat, Singang, Jangan Bage, Surabi. Selam Matano, Sampan, and Jukung. The lexicon of Jembatan means bridge, where this lexicon can be seen and found in the coastal area and the rivel are of Sumbawa regency, West Nusa Tenggara Province of Indonesia. It is categorized into the noun lexicon. Then, the lexicon of Polak and Besai categorized into the adjective lexicon. Polak means broken and besai means to unite. Next, the lexicon of Sepat, Singang, Jangan Bage and Surabi were categorized into noun lexicon. These lexicons refer to the famous local food names in Sumbawa people. The lexicon of Selam Matano categorized into the noun lexicon. Selam Matano mean Sunset, it was the time of day when the sun disappears and night begins, and Sumbawa people used to this moment for sitting and relaxing in Jempol beach. The lexicon of Sampan and Jukung categorized into the noun lexicon. Sampan means local canoe of Sumbawa peole. It was a long, light boat pointed at both ends and moved along using a traditional paddle. Jukung means local dinghy. It was a traditional small open boat used for pleasure or used to take people between a ship and the shore.

\section{Goa Beach}

Goa beach location is not too far from the center of Sumbawa Besar, it might only take about 15-20 minutes by car, because the distance is only about 5 kilometers from the city center, it is in front of the army quarter of Sumbawa Senapan II. Visitors can go by a general vehicle by boat, bus, taxi, motorcycle, dogcart, sailboat, and pedicab. 
Goa beach is well-known by the people when the Bajo tribe of Utan immigrants from South Sulawesi moves to the beach's coast. They live on the coast as fishermen and traders. Shortly after they settled there, they find a cave where the invaders use it as their settlement. It begins with many people from Sumbawa and outsider visited the Goa beach. They come to see a small cave left over by the invaders, and then it named "Goa beach". Henceforth, Bajo tribes who work as fishermen begin to open food stalls that provide grilled seafood on the main menu, such as singang, sepat and jangan tunung, those Sumbawa culinary, and other archipelago foods. Additionally, this beach also often releases baby turtles event into the sea. Indeed, it is not far from this beach. There is also a conservation center for almost extinct sea turtles. (Sources: Taken from private document)

The English reading text of Goa Beach founded some of the ecoliteracy lexicons, which are the characteristics of these texts. The lexicons involved in this text were Goa, Bajo, Singang, Sepat and Jangan Tunung lexicons. The lexicon of Goa categorized into noun lexicon. The lexicon of Goa means cave. Goa lexicon refers to a small hole in a coastal area located in the northern part of Sumbawa. It was a very famous cave in this regency. Then, bajo lexicon categorized into the noun lexicon. Bajo means one of the tribes who has been living on Sumbawa island. They immigrated from South Sulawesi island. In general, bajo tribe divided into tau sama and bagai. Tau sama refers to bajo people who lived and settled in coastal areas, and bagai refers to bajo people who lived in the land, and they interacted and communicated with other tribes in the land. The lexicons of Singang, Sepat and Jangan Tunung categorized into the noun lexicon. They belonged to the local culinary of Sumbawa island.

\section{Matti Mindai Beach}

Matti Mindai beach is a beautiful hidden beach with a not long coastline. Matti Mindai beach is approximately one hour from Labuhan Terata village. Matti Mindai beach location is in Gili Dua in front of Ngali island. It is part of the administrative territory Lape district. Visitors come to this beach by a local boat, jukung (local sailing vessel), and sampan.

The reason this beach call "Matti Mindai", beacuse Mandar tribe live in front of the beach who is an immigrant from West Sulawesi. "Matti Minddai" is derived from Mandarness means in Indonesia Language "Timbul Tenggelam" in English is embossed drowning or ebbtide beach. "Matti" means drowning or sinking and "Minndai" means embossed. It means that this beach will be visible when the seawater is flux; otherwise, this beach will not be seen when the seawater is reflux. Matti Mindai beach has a unique form of sand. The sand on this beach is reddish, it looks star-shaped, and white sand is formed from the remnants of dead sea corals. Furthermore, Matti Minddai beach is flanked by two girls, namely Gili Dua and Gili Dua Cecceng. (Sources: Taken from a private document)

Based on the English reading text of Matti Mindai Beach. It founded some of ecoliteracy lexicons which as the characteristics of these texts. Those of the lexicons related to this text were Matti, Mindai, Gili Dua, Gili Dua Kayyang (big dua gili) and Gili Dua Cecceng (small dua gili). The lexicons of Matti and Mindai categorized into the adjectives lexicon. These lexicons derive from the Mandarness of West Sulawesi, the lexicon of Matti means drowning or sinking and the lexicon of Mindai means embossed. The terms of Matti Mindai refers to the characteristic of this beach visible when the sea water was a flux, and it was not seeing while refluxing the sea water. Futhermore, Gili Dua, Gili Dua Kayyang and Gili Dua Cecceng categorized the lexicons into the noun lexicons. Gili Dua means two islands nearby the Matti Mindai beach. Gili Dua Kayyang means the first big island, and Gili Dua Cecceng means the second small island. The lexicon Kayyang and Cecceng categorized into the adjective noun, which Kayyang means big and Cecceng means small. Both of these lexicons derive from Mandar language, which was one of the local languages in Indonesia.

\subsection{English Reading Text Based-Historical Architecture Environment Lexicons.}

There were two lexicons found in the English reading text Based-Historical Architecture Environment Lexicons. The topics of the reading text related to the Historical Architecture Environment Lexicons. These lexicons were Dalam Loka Palace and Bala Puti Palace. The sample of the reading text discussed in the following:

\section{Dalam Loka Palace}

Dalam Loka palace is a historical witness that shows the glory of the Sumbawa Sultan. It was built in 1885 . The construction of the building, which means the old palace, was initiated by Sultan Muhammad Jalaluddin Syah III, who became the 16th Sultan of the Dewa Dalam Dynasty. Dalam Lokal palace stands firmly in the center of Sumbawa Besar city, West Nusa Tenggara Province.

Dalam Loka palace is a traditional house of Tau Samawa. This palace is a Rumah Panggung with a building area of 904 Meters. Dalam Loka palace looks very majestic because it was built using large wooden taken from the Sumbawa forest. This palace that was built with wood has a philosophy of "adat berenti ko syara, syara barenti ko kitabullah", which means that all the rules of customs and values in the joints of life Tau Samawa must be encouraged in Islamic law. Furthermore, the symbol of Islam can also be seen in the wooden support totaling 99 
poles which, if interpreted to have similarities in accordance with the Name of Allah (Asmaul Husna) in the Qur'an Karim. The main building, called the bala rea (large room) built with teak wood as a substitute for the king's residence who had been burned during the royal gunpowder eruption. This palace was built with a Baji (wedge) system. This building has a high level of flexibility when an earthquake occurs. The selection of the south as the direction towards the house also has its own meaning. Based on the law of the cardinal direction, the south is believed to be able to provide a cool, serene, peaceful and comfortable atmosphere. Not only that, the south also means looking at the past, which, when interpreted, leaders must have wisdom and wisdom in addressing the past that can be brought to the present. Before Dalam Loka palace builds in the same location, several royal palaces had been built. Among them are Bala Balong Palace, Bala Sawo Palace and Gunung Setia Palace. The palaces were rotted with age; even some were burned out in the fire. Nowadays, the Dalam Loka Palace has functions as cultural preservation that reminds if the Sumbawa Sultanate has a golden-age in a long time ago. (Sources: Taken from a private document)

Based on the English reading text of Dalam Loka Palace. It founded some of ecoliteracy lexicons, which as the characteristics of this text. The lexicon involved in this text were Dalam Loka, Tau Samawa, Rumah Panggung, Adat, Berenti, Syara, Kitabullah, Asmaul Husna, Baji, Bala Sawo, Bala Balong and Gunung Setia palace. The lexicon of Dalam Loka categorized into the adjective phrase lexicon. The lexicon Dalam Loka derive from sumbawa language, which the lexicon of Dalam means inside and the lexicon of loka means old. Then, the lexicon of Tau Samawa categorized into noun phrase lexicon. Tau Samawa means the native speaker who lived in Sumbawa island. Lexicon Tau means people, and Samawa means the Island. The lexicon of Rumah Panggung categorized into the noun phrase lexicon. Rumah Panggung means the wooden house. Rumah Panggung was the stage building with the power of the construction system in each element. The lexicon of Adat categorized into the noun lexicon. Lexicon of Adat means culture. The lexicon of Berenti categorized into the verb lexicon. Barenti means be guided. The next the lexicon of Syara categorized into the noun lexicon. The Syara lexicon adopted from Arabic word, alshrye means the rule base on the religious law. The lexicon of Kitabullah was also adopted from an Arabic word, which means the Al Qur'an from the God al Mighty. The lexicon of Asmaul Husma categorize into the noun phrase lexicon. Asmaul Husna also adopted from an Arabic word, which means the 99 of Allah name in the Al Qur'an. The Baji lexicon originally comes from sumbawa language that means wedge. The Baji lexicon is categorized into the noun, which Baji was a piece of wood having one thick end and tapering to a thin edge, driven between two objects of an object to secure or separate them. The lexicons of Bala Sawo, Bala Balong and Gunung Setia palace categorized into the noun phrase lexicons. The bala means house. It derives from Macassar language in South Sulawesi.

\section{Bala Puti Palace}

Bala Puti Palace is built by Sultan Muhammad Kaharruddin III who continued the throne of Sultan Muhammad Jalaluddin Syah III. The construction of this palace carried out in 1932-1934. When entering the Bala Puti Palace gate, it remains the history of the Dutch colonial occupation in Indonesia.

Bala Puti Palace, with colonial architecture becomes an important palace in the history of Sumbawa. Bala Puti palace is a priceless piece of history. The Bala Puti palace resembles the Taj Mahal in India, which was built during the time of Emperor Shah Jahan as a musoleum in memory of his beloved wife, Queen Mumtaz Mahal. Likewise,Tau Samawa perception, the Bala Puti palace symbolizes Sultan Sumbawa's love for the empress and her people. Bala Puti palace is a love offering to Sultan Bima's daughter, Siti Khadijah Daeng Ante, Ruma, His Majesty, the daughter of Sultan Muhammad Salahuddin. In front of the palace stands the Bale Jam building, a special place to place a time-marking bell. In the southern part of the palace, Sumer Batir is a sacred well whose water is one of the four types of leased water that completes the life cycle ceremony of the Sumbawa Sultanate palace. Another attraction in the palace complex area has a large yard with a beautifully arranged garden that visitors can see a herd of Sumbawa deer in the eastern courtyard of the palace. This palace has added a door in front of the Balairung Sari Room as a space for MICE activities (meetings, incentives, conventions, and exhibitions). Bala Puti palace is dominated by white paint which means purity as proof of the immortality of love, loyalty, and sacrifice of two people in realizing the promise of love. (Sources: taken from a private document).

Based on the English reading text of Bala Puti Palace. It founded some of ecoliteracy lexicons, which as the characteristics of this text. The lexicon involved in this text were Bala Puti, Bale Jam, Sumer Batir, and Balairung Sari. Bala Puti was categorized into the noun phrase lexicon. Bala Puti lexicon adopted from Macassar and Sumbawa language. Bale was Macassar word, which means house, and Puti was Sumbawa word, which means white. So the lexicon of Bala Puti means white house. It looked like a musoleum of Taj Mahal in India. The lexicon of Bale Jam also was categorized into the noun phrase lexicon. Bale Jam original come from Sumbawa language, which Bale mean house, and Jam means clock. The Bale Jam was a house that built like a clock model. The lexicon of Sumer Batir was categorized into the noun phrase lexicon. Sumer Batir means well, and Batir means red stone. The noun phrase of Sumer Batir was a deep hole made from the red stone in the ground from which the only king's family 
permitted for taking its water. Then, the Balairung Sari lexicon was categorized into the noun phrase lexicon. Balairung adopted from Macassar word, which means open room for the public, and Sari means core. The Balairung Sari means the room used for meetings, incentives, conventions, and exhibitions in the Bala Puti Palace.

\subsection{English Reading Text Based- Marine Achipelagos Environment Lexicons.}

The English reading text-based marine archipelago environment lexicons consist of two lexicons: Moyo Island and $\mathrm{Ngali}$ Island. The explanations of the text type in the following:

\section{Moyo Island}

Moyo Island is not far from Sumbawa Island. It is at the mouth of Saleh Bay. It is a small island and nature reserve located 3 kilometers off the northern coast of Sumbawa Island. Getting to Moyo island by car from Sumbawa Besar to Ai Bari, a coastal village located 20 kilometers north of Sumbawa Besar, then charter a boat on the spot, sail across in Ketinting, which is a local fishing outrigger, or preferred a helicopter transfer from Bali directly to Moyo, which is of course possible.

Moyo Island is still an unspoiled and favourite exotic destination for overseas celebrities to hide away from paparazzi such as Lady Diana and Maria Sharapova. Moyo Island is a pristine environment with rugged coastlines and a grassy savannah home to all sorts of wildlife. It has a variation in altitude of 0-648 meters above sea level and has an area of 30,000 hectares. Moreover, it is a natural environment of this island of hundreds of butterflies that can be seen flying about behind bushes, around trees or in the middle of the savanna. It is home to 21 species of bats, birds, macaques, wild pigs, deer and snakes. It is also a paradise for bird lovers. Then, there are 124 bird species found in Sumbawa. 86 are found on the island. It finds rare bird species on this island, are yellow-headed parrots and megapodes, which are chicken-like birds, also known as Pio Bereton. The megapode is a unique bird because it builds a large mound of debris to incubate its eggs with the heat of decomposition. It has a beautiful dense forest, cascading waterfalls, natural rivers, and an aquatic wonderland bursting life, several caves. One of them is Ai Manis cave. It can also do marine activities like snorkeling, swimming, and diving. (Sources: Taken from a private document)

Based on the English reading text of Moyo Island. It founded some of ecoliteracy lexicons which as the characteristics of this text. The lexicons included in this text were Ai Bari, Ketinting, Pio Bereton and Ai Manis Cave. The lexicon of Ai Bari categorized into noun phrase derive from Sumbawaness. Ai means water and Bari means a local tree in Sumbawa. The Ai Bari lexicon was the name of the village the closed with sea and in this village, many grown Bari tree in the are of this village. The lexicon of Ketinting original come from Sumbawa language. Ketiting means a traditional dinghy of sumbawa people and the motor machine taped on the right side of the dinghy. The lexicon of Pio Bereton was categorized into the noun phrase lexicon. Pio means bird, and Beretong means big egg. The Pio Beretong was a bird that having a big egg or megapodes. Next, the lexicon of Ai Manis Cave categorized into the noun phrase lexicon. The lexicon Ai means water, and Manis means sweet. So the Ai Manis Cave refers to a cave in Moyo Island that has sweet water on the side of this cave.

\section{Ngali Island}

Ngali Island is belong to the area of Labuhan Kuris Village, Lape District, Sumbawa Regency. Getting to this island takes around two hours to reach this island from the port of Labuhan Terata settlement which is Bugis tribe settlement.

Ngali Island begins to raise its name on the surface during the Tambora Festival in 2016. This island is known as the center of an ancient kingdom namely Ngali Shiwa and it is almost forgotten. The history of the island tries to be refreshed by the existence of creative community-based tourism development activities that begin with Alunan Semesta Gili Ngali, part of the tambora pilgrimage. In this activity, the National Cultural, his name is Taufik Rahzen, the Ministry of Tourism brought 12 national and international artists. Among them are Ray Sahetapi (Indonesia), Sean Hayward (America), Kate Liddle, Jade Flahive, and Anita Rhona Watson, three from England, Dilki Pahanthihage (Sri Lanka), Ellen Begw Jordan (Wales), Victor Hugo Hidalgo and Leon Berto Medellin from Mexico, as well as several other national artists. Daeng Lombeng and his family firstly live on this island. The people of this island are Mandar tribe from West Sulawesi. They speak with Mandarness as their daily language communication. On this island the people work as fishermen, cattlemen, and farmer. They hunt Sabalah and catch the fish. The people use solar power as their lighting on this island. On this island live only seven patriarchs. The population of this island is around 25 people. Besides, the people drink Wai Buyung and Wai Urang. The people always keep Wai Urang in the rain barrel during the rainy season. The people will drink the Wai Urang in the dry season. (Sources: taken from a private document). 
Based on the English text of the Ngali Island. In this text, the writer found some of the ecoliteracy lexicons. The lexicons were Tambora Festival ,Ngali Shiwa, Sabalah, Wai Urang, Wai Buyung and Wai Urang. Tambora Festival was categorized into the noun phrase. The lexicon of Tambora Festival means Tambora pilgrimage. This pilgrimage ceremonial held to celebrate the eruption of the mountain of Tambora in 1815. Ngali Shiwa categorized into the noun phrase. This lexicon was nine islands in the Saleh bay in Tambora. Then the lexicon of Sabalah catgorized into the noun. The mean of Sabalah was cucumber sea. It derived from Mandar language because the people who lived in this area immigrated from West Sulawesi and were spoken by Mandarness. The next, the lexicon of Wai Buyung categorized into the noun phrase. The meaning of Wai Buyung was well-water. This lexicon also belongs to Mandarness, the reason people called Wai Buyung, because they took water drinking from the well in the Dempu Island. There was only one well for freshwater as their drinking water for Mandar tribe in this area. Then, the lexicon of Wai Urang was categorized into the noun phrase. The Wai Urang lexicon means rain-water. The Mandar tribe in this territory used to keep the well-water in the rain barrel when the rainy season, and they keep the Wai Urang for their drinking water in the dry season.

\subsection{English Reading Text-Based-Traditional Farmland Environment Lexicons.}

The English reading text-based traditional farmland environment lexicons consist of two lexicons, including the lexicon of Orong and Uma. The discussion of both lexicons is the following:

\section{Orong}

Orong original comes from the Sumbawa language. Orong is a word of the terms used by Tau Samawa for giving name their rice fields. Orong has a function as land to plant paddy of larger quantities.

Orong is rice fields that the parents inherit from their children. The division of Orong is adjusted to the amount of Orong and the number of their children. In general, parents who have two Lingkung Orong will give all to their children if the child is a Tode Mesa. Whereas parents have two children, they will get the same large of Orong, equal both son and daughter. Orong has an area of at least two hectares. One Lingkung Orong usually consists of 12 Bangkat or plot. A Lingkung Orong can be planted with paddy (Blek is a traditional measuring device), which 8 Blek is weighed around 80 kilograms. In general, Tau Samawa recognize two types of Orong, namely Orong Rea and Orong Ode. Orong Rea is a rice field that consists of many owners. In other words it consists of many Lingkung Orong in the same location. While Orong Ode is a rice field whose owner usually consists of just five people. Previously, Orong was hijacked by using traditional tools such as two buffalos and hoe before using a handtractor. Orong plant paddy uses two ways: plant Anak Pade and Bineng Pade. Furthermore, The paddy in the Orong was harvested by two systems. Those are Nyinggu and Basiru systems. Paddy plant twice a year in the Orong, because it used water from the barrage. (Sources: Taken from a private document)

Based on the English text of the Orong ecolexicon. The ecolexicons related to this topic were Orong, Tode Mesa, Blek, Orong Rea, and Orong Ode. The lexicon of Orong categorized into the noun. The meaning of this lexicon was the biggest traditional rice farm. It was derived from Sumbawa language. Then, Tode Mesa categorized into the noun, which means begotten of. The lexicon of Blek categorized into the noun. The meaning of Blek lexicon was a traditional measuring device of Sumbawa people for measuring paddy before selling their paddy. The Orong Rea was categorized into the noun phrase. The meaning of Orong Rea was rice field that consists of many owners. The lexicon of Orong Ode was categorized into a noun phrase. The meaning of Orong Ode was a rice field whose owner usually consists of only five person.

\section{Uma}

Uma wasderived from Sumbawaness. Uma means a term for the traditional farmland of rice in the Sumbawa village. Uma is specifically a terrain for planting rice not to exceed the quantities.

Uma is also a rice field that the parents give to their children. Uma's division depends on the amount of their mind and their children. Casually, parents have only one Uma and their children are three people, it will go fiftyfifty to each them either boy or sister. Usually, Uma consists of two to six Bangkat or plot. Uma has a large size, approximately maximum of one hectare. In reality, now, a person mostly has 3 Bangkat or plot for each Uma. Henceforth, one Uma usually consists of three owners. An Uma can be planted four of Blek paddy, heavily 40 kilograms. Commonly, Tau Samawa keeps saying two types of Uma, based on their Uma's distance from the main street. Those are Uma Luar and Uma Dalam. Uma Dalam is a traditional rice farm, a rice farm in front of the highway, whereas Uma Dalam is a rice field about 300 meters on the main street. Uma also ploughs with two buffalos, hoe, Rengala, and Kareng. Today Uma cultivates using a cultivator and a hand tractor. Uma plant rice with either Nanam Anak Pade or Nyecor ways. In addition, rice in the Uma harvests with both Nyinggu and Basiru systems and uses a combined harvester. Uma is planted by rice twice a year, the water takes from Ai Embung (barrage-water), and it uses from Ai Ujan (rain-water). (Sources: Taken from a private document) 
Based on the English text of the ecolexicon of Uma. The ecolexicons of Uma involved Uma Luar, Uma Dalam, Ai Embung and Ai Ujan. The lexicon of Uma was categorized into the noun. The meaning of Uma was a term for the traditional farm land of rice in the Sumbawa village. It was smaller than Orong. Then, Uma Luar was categorized into the noun phrase. The lexicon of Uma Luar derived from Sumbawaness. The meaning of Uma Luar was a traditional rice farm, this rice farm whose position was in front of the highway. Apposite, the lexicon of Uma Dalam was categorized into a noun phrase. The meaning of the lexicon Uma Dalam was a traditional rice field that was about 300 meters on the main street. The lexicon of Ai Embung was categorized into the noun phrase. It was original derive from Sumbawa language. Ai Embung means barrage-water, this water used for watering the paddy in the dry season. The last, the lexicon of $A i$ Ujan was categorized into the noun. The meaning of Ai Ujan lexicon was the rain-water. The Ai Ujan has the function for watering the paddy in the rainy season.

\section{Conclusion}

English reading textbooks often present some lexicons for constructing and developing the text related to the author's environment perspective. There was no illustration and explanation for students when some of the lexicons were used. This study has tried to reveal the benefit of introducing the ecoliteracy lexicon in English language teaching, especially for teaching reading skills for local students in Sumbawa regency, West Nusa Tenggara province of Indonesia. The formulations of the ecoliteracy lexicon in descriptive reading text determine and develop the material in teaching reading skill, especially for the senior high students both in English and in Sumbawa language. The English reading text in this study provided some topics such as; 1). English Reading Text Based-Beaches Marine Lexicons. There were two ecology lexicons in this topic: 1) the lexicon of Jempol Beach and Goa Beach lexicon. 2). English Reading Text Based-Historical Architecture Environment Lexicons. The ecolexicon of this study consisted of the lexicon of Dalam Loka palace and Bala Puti Palace, and 3). English Reading Text Based-Marine Achipelagos Environment Lexicons. The lexicons related to the ecological in this topic were Moyo Island and Ngali Island lexicon. The last, 4). English Reading Text Based- Traditional Farmland Environment Lexicons. This topic consists of two ecolexicon were the lexicon of Orang and Uma.This text developed to enrich the students' knowledge to understand reading texts related to their ecoliteracy. By using and doing this practice text for senior students, the material has to be expanded. In addition, it has been acknowledged that there was a lack of research exploring the difficulties of comparing English and Sumbawaness in developing English reading text. Future research was needed to enrich the developing local material, especially on English teaching reading skill.

\section{References}

[1] Bergenholtz, Henning \& Trap, Sven.(1995).Manual of Specialised Lexicography. Amsterdam: John Benjamin Publishing.

[2] Borg, R, Meredith GI.(1983).Educational Research: An Introduction. New York \& London: Longman.

[3] Borg, R, Meredith Damin Gall.(2003).Educational Research: An Introduction. New York: Allyn and Bacon.

[4] Capra, F.(1995). The Web of Life, Harper Collins. Tersedia Online di http://www.ecoliteracy.org/publica tions/frijop: Accesed on March, 17, 2021.

[5] Chaer, A.(2007). Leksikologi dan Leksikografi Indonesia. Jakarta: Rineka Cipta.

[6] Dick \& Carey.(2005). The Systematic Design Instruction. Pearson: Boston.

[7] Hariati.(2018). Peningkatan Kemampuan Siswa Dalam Memahami Bacaan Bahasa Inggris Melalui "Deducing Meaning From Context" Eralingua: Journal of Pendidikan Bahasa Asing dan Sastra, 2(1), 79.

[8] Hyun,E.(2000). Ecological Human Brain and Young Children's 'Naturalist Intelligence' from the Perspective of Developmentally and Culturally Appropriate Practice (DCAP). Presented at the Annual Conference of the American Educational Research Association. New Orleans, LA: American Educational Research Association.

[9] Kridalaksana.(2008). Kamus Linguistik. Jakarta: Gramedia Pustaka Utama.

[10] Megawati,F.(2016). Kesulitan Mahasiswa Dalam Mencapai Pembelajaran Bahasa Inggris Secara Efektif. Journal of Pedagogia, 5, (2),153-154.

[11] Nurgiyantoro, B. (2010). Sastra Anak: Pengantar Pemahaman Dunia Anak. Yogyakarta: Gadjah Mada University Press.

[12] Rahmawati,I.,F. (2011). Improving Eighth Graders' Reading Comprehension through Autonomous Strategy.. [Unpublished Study]. Muhammadiyah University.

[13] Rubin, D.(2011). A Practical Approach to Teach Reading. Boston: Allyn dan Bacon.

[14] Setiawan, T.(2015). Leksikografi: Penerbit Ombak: Yogyakarta.

[15] Somadayo, S.(2011). Strategi Dan Teknik Pembelajaran Membaca. Yogyakarta: Graha Ilmu.

[16] Suryaman, M.(2012). Metodologi Pembelajaran Bahasa. Yogyakarta: UNY Press.

[17] Tarigan, G., H.(2008). Membaca Sebagai Suatu Keterampilan Berbahasa. Bandung: Angkasa.

[18] Verhaar, J.,W.,M.(2016). Asas-Asas Linguistik Umum. Yogyakarta: Gadjah Mada University Press.

[19] Yunus, A.(2012). Pembelajaran Membaca Berbasis Pendidikan Karakter. Bandung: PT. Refika Aditama.

[20]Yusril, Y., Mantasiah, R., \& Jufri, J.(2018). The Use of Two Stay Two Stray Model in English Teaching to Increase Student's Learning Outcome. Journal of Advanced English Studies, 1(1), 39-43. 